\title{
Evaluasi Kadar Gula Darah Pasien Berdasarkan Kajian Usia dan Komplikasi Penyakit pada Pasien Diabetes Mellitus Tipe-2 di Puskesmas Jetis 1 Bantul Periode September-November 2019
}

\author{
Caesar Bagus Reyaldi ${ }^{1}$, Akrom $^{1}$ dan Susan Fitria Candradewi ${ }^{1}$ \\ ${ }^{1}$ Faculty of Pharmacy, University of Ahmad Dahlan, Yogyakarta, 55164.
}

Reception date of the manuscript: 28 Desember 2020

Acceptance date of the manuscript: 14 Agustus 2021

Publication date: 31 Desember 2021

\begin{abstract}
Diabetes mellitus is a chronic disease which causes blood sugar levels increase. Increasing age affects performance of body organs function against insulin which leads to fluctuations in blood sugar. Decreased performance of body functions affects balance of other body functions which can cause complications. The research objective was to evaluate blood sugar levels based on age and disease complications. The research design used was analytic observational research. Data were collected retrospectively from September - November 2019. Univariate analysis is used to analyze basic characteristics of research variables. Bivariate analysis was used to determine differences in patient blood sugar based on age and disease complications. The statistical test used is the Kruskal Wallis test. The results showed blood sugar levels based on the age obtained is $0.289 ; 0,242 ; 0,150 ; 0,658 ; 0,557 ; 0.711(p>0,05) ; 0.040(p<0,05)$. Test results based on disease complications were $0.317 ; 0.626 ; 0.121 ; 0.932 ; 0.658 ; 0.214 ; 0.104(p>0,05)$. The conclusion is there is no significant difference in blood sugar levels of patients based on age and complications of the disease in the period September 2019 - November 2019. Diabetes mellitus patients had controlled blood sugar levels based on age and disease complications.
\end{abstract}

Keywords-Type-2 Diabetes Mellitus, Age, Disease complication.

\begin{abstract}
Abstrak- Diabetes mellitus merupakan penyakit kronis yang membuat kadar gula darah meningkat. Bertambahnya usia mempengaruhi kinerja fungsi organ tubuh terhadap insulin mengarah terjadinya fluktuasi gula darah. Turunnya kinerja fungsi tubuh berpengaruh dalam keseimbangan fungsi tubuh yang lain sehingga dapat menyebabkan komplikasi. Penelitian yang dilakukan bertujuan untuk mengevaluasi kadar gula darah berdasarkan usia dan komplikasi penyakit. Rancangan penelitian yang dilakukan adalah penelitian observasional analitik. Pengambilan data dilakukan secara retrospektif dari bulan September - November 2019. Analisis univariat digunakan untuk melihat analisis karakteristik dasar variabel penelitian. Analisis bivariat digunakan untuk mengetahui perbedaan gula darah pasien berdasarkan usia dan komplikasi penyakit. Uji statistik yangdigunakan adalah uji Kruskal Wallis. Hasil penelitian menunjukkan kadar gula darah berdasarkan usia yang diperoleh adalah 0,$289 ; 0,242 ; 0,150 ; 0,658 ; 0,557 ; 0,711(p>0,05) ; 0,040(p<0,05)$. Hasil uji berdasarkan komplikasi penyakit didapatkan 0,$317 ; 0,626 ; 0,121 ; 0,932 ; 0,658 ; 0,214 ; 0,104(p>0,05)$. Berdasarkan hasil penelitian, dapat disimpulkan tidak ada perbedaan signifikan kadar gula darah pasien berdasarkan usia dan komplikasi penyakit pada periode September 2019-November 2019. Pasien memiliki kadar gula darah yang terkontrol berdasarkan usia dan komplikasi penyakit.
\end{abstract}

Kata Kunci-Diabetes Melitus Tipe-2, Usia, Komplikasi Penyakit.

\section{Pendahuluan}

Diabetes mellitus adalah penyakit kronis yang terjadi ketika kadar gula dalam darah naik disebabkan oleh tubuh yang tidak dapat memproduksi hormon insulin yang cukup atau menggunakan insulin secara efektif (International Diabetes Federation, 2017). Diabetes mellitus menjadi faktor risiko

Penulis koresponden: Caesar Bagus Reyaldi, Email: caesar1600023082@webmail.uad.ac.id untuk penyakit kardiovaskular, gagal ginjal, gagal jantung, dan stroke. Menurut American Diabetes Association (2018), diabetes mellitus diklasifikasikan menjadi empat yaitu diabetes mellitus tipe-1, diabetes mellitus tipe-2, diabetes mellitus gestasional dan diabetes mellitus tipe lain.

Tren penyakit diabetes mellitus di Indonesia terus meningkat. Berdasarkan WHO (2016), total prevalensi diabetes mellitus di Indonesia sebesar $6 \%$ dilanjutkan oleh IDF (2017) sebesar 6,2\% dan diprediksi pada 2045 mencapai 7,4\%. Menurut Konsensus PERKENI (2015) dalam Riskesdas (2018), prevalensi pada penduduk umur 15 tahun adalah $10,9 \%$. Be- 
sarnya angka prevalensi yang terkena diabetes mellitus perlu diperhatikan agar pasien sukses mencapai target terapi.

Profil kesehatan Kabupaten Bantul menyebutkan bahwa diabetes mellitus termasuk ke dalam 10 besar penyakit di puskesmas dengan angka kunjungan yang terus meningkat (Dinkes Bantul, 2018). Jumlah kunjungan pasien diabetes mellitus memperlihatkan angka yang cukup tinggi di Puskesmas Jetis 1 Bantul. (Anonim, 2017).

Usia adalah faktor risiko yang dapat meningkatkan prevalensi penderita diabetes mellitus tipe 2 . Prevalensi penderita diabetes mellitus pada lanjut usia ( 65 tahun) adalah $20 \%$ lebih dari delapan kali lebih tinggi daripada orang dewasa berusia 18-44 tahun (2,4\%) pada 2011 di Amerika Serikat. Peningkatan pada penderita lanjut usia terjadi karena gangguan sekresi insulin menyebabkan terjadinya diabetes daripada penderita orang dewasa (Selvin et al., 2013). Hasil Riskesdas (2018) menunjukkan peningkatan prevalensi diabetes mellitus seiring bertambahnya usia. Prevalensi terbanyak terjadi pada golongan usia 55-64 Tahun.

Berdasarkan Riskesdas (2018), menunjukkan terjadinya peningkatan penderita diabetes mellitus seiring bertambahnya usia. Prevalensi penderita diabetes mellitus berdasarkan usia meningkat dikarenakan kurangnya sekresi sel insulin karena resistensi insulin atau penggunaan insulin yang tidak efektif. Resistensi insulin dapat diakibatkan karena menuanya usia sehingga otot kerangka ikut menua. Otot kerangka yang menua mengakibatkan terjadinya disfungsi mitokondria, akumulasi lipid intramioseluler, meningkatnya inflamasi, stres oksidatif, aktivitas modifikasi enzim pengatur sensitivitas insulin, stres retikulum endoplasma, penurunan autofagi, sarkopenia, dan sistem renin-angiotensin yang terlalu aktif dapat mengganggu sensitivitas insulin otot rangka dan meningkatkan risiko resistensi insulin dan diabetes tipe 2 (Shou et al., 2020) Sensitivitas insulin yang terganggu menyebabkan kekurangan insulin lalu mengarahkan sistem metabolisme menjadi tidak seimbang dan menyebabkan komplikasi penyakit.

Menurut PERKENI (2019), glukosa plasma puasa (glukosa plasma naughter) $152 \mathrm{mg} / \mathrm{dL}$ saat tidak ada asupan kalori minimal 8 jam, glukosa 2 jam post prandial $176 \mathrm{mg} / \mathrm{dL}$, glukosa plasma sewaktu $154 \mathrm{mg} / \mathrm{dL}$ dengan keluhan klasik atau $\mathrm{HbA} 1 \mathrm{c} 7 \%$ dikatakan tidak terkontrol.Obat hiperglikemik oral, insulin maupun kombinasinya dapat diberikan jika melebihi dari kadar tersebut. Algoritma terapi farmakologi diabetes mellitus tipe 2 di Indonesia diberikan kepada pasien yang terdiagnosa diabetes mellitus. Pemberian terapi farmakologi ini dengan tujuan mengontrol kadar gula darah pasien (PERKENI, 2019).

\section{MetOde}

Rancangan penelitian yang digunakan adalah penelitian observasional analitik. Data diambil secara retrospektif dengan cara pengumpulan data melalui rekam medis pasien pada Bulan September - November 2019. Jenis dan sumber data bersumber dari data sekunder. Data sekunder berisi karakteristik pasien, kadar gula darah, komplikasi yang diambil dari catatan rekam medis. Sampel ditentukan berdasarkan populasi penelitian yang memenuhi kriteria inklusi. Penentuan besar sampel menggunakan kalkulator open epi (online) melalui sample size Unmatched case contol study. Hasil dari perhitungan sampel adalah 46 pasien.
TABEL 1: KARAKTERISTIK PASIEN

\begin{tabular}{lcc}
\hline Karakteristik & Jumlah $(\mathbf{n}=\mathbf{4 6})$ & Persentase ( \%) \\
\hline Usia & 30 & 65,2 \\
35-64 Tahun & 16 & 34,8 \\
65 Tahun & & \\
Jenis Kelamin & 30 & 65,2 \\
Perempuan & 16 & 34,8 \\
Laki-laki & & \\
Komplikasi Penyakit & 33 & 71,7 \\
Ada komplikasi penyakit & 13 & 28,3 \\
Tidak ada komplikasi & & \\
penyakit & 46 & 100 \\
Status Pernikahan & 0 & 0 \\
Sudah menikah & & \\
Belum menikah & 17 & 37 \\
Status Pekerjaan & 29 & 63 \\
Bekerja & & \\
Tidak Bekerja & 8 & 17,4 \\
Status Pendidikan & 22 & 47,8 \\
Tidak Sekolah & 14 & 30,4 \\
Dasar & 2 & 4,3 \\
Menengah & & \\
Tinggi & &
\end{tabular}

Definisi operasional penelitian yang digunakan adalah Gula Darah Sewaktu (GDS) ialah gula darah yang diambil saat pasien ke puskesmas dalam keadaan sedang tidak berpuasa. Batas GDS yaitu 154 mg/dL (PERKENI, 2019); Gula Darah Naughter (GDN) atau Gula Darah Puasa (GDP) adalah kadar gula darah yang diukur saat pasien berpuasa makan selama 8 jam. Batas GDP atau GDN yaitu $152 \mathrm{mg} / \mathrm{dL}$ (PERKENI, 2019); Gula Darah 2 Jam Post Prandial (GD2JPP) adalah hasil pengukuran kadar gula darah pasien 2 jam setelah makan. Batas GD2JPP yaitu 176 mg/dL (PERKENI, 2019); HbA1C adalah hasil pemeriksaan kadar gula darah dari gula yang berikatan dengan hemoglobin. Batas HbA1C adalah $7 \%$ (PERKENI, 2019). Komplikasi adalah penyakit yang diderita pasien setelah didiagnosa diabetes mellitus atau hadir saat masa rawat jalan diabetes mellitus.

Data dianalisa dengan analisis bivariat dan univiariat. Analisis univariat digunakan untuk melihat data sosiodemografi. Analisis bivariat digunakan untuk mencari perbedaan pada usia dengan gula darah dan komplikasi penyakit dengan gula darah. Uji statistik yang digunakan adalah uji Kruskal Wallis.

\section{HASIL}

Hasil penelitian adalah Tujuh pasien melakukan pengukuran gula darah sewaktu terdiri atas 4 pasien $(8,7 \%)$ dengan usia 35-64 tahun dan 3 pasien $(6,5 \%)$ dengan usia 65 tahun, 39 pasien melakukan pengukuran gula darah naughter atau gula darah puasa terdiri atas 26 pasien $(56,5 \%)$ dengan usia 35-64 tahun dan 13 pasien $(28,3 \%)$ dengan usia 65 tahun pada bulan awal terapi. Sembilan pasien melakukan pengecekan gula darah sewaktu terdiri atas 7 pasien $(15,2 \%)$ dengan usia 35-64 tahun dan 2 pasien (4,3\%) dengan usia 65 tahun. 37 pasien melakukan pengukuran gula darah naughter terdiri atas 23 pasien (50\%) dengan usia 35-64 tahun dan 14 pasien $(40,5 \%)$ dengan usia 65 tahun pada bulan kesatu. Enam pasien melakukan pengukuran gula darah sewaktu terdiri atas 3 pasien $(6,5 \%)$ dengan usia 35-64 tahun dan 3 pasien $(6,5 \%)$ dengan usia 65 tahun, 31 pasien melakukan 
pengukuran gula darah naughter terdiri atas 23 pasien $(50 \%)$ dengan usia 35-64 tahun dan 8 pasien $(17,4 \%)$ dengan usia 65 tahun dan 9 pasien melakukan pengukuran $\mathrm{HbA} 1 \mathrm{C}$ terdiri atas 4 pasien $(8,7 \%)$ dengan usia 35-64 tahun dan 5 pasien $(10,9 \%)$ dengan usia 65 tahun pada bulan kedua.

Hasil menunjukkan tidak ada perbedaan signifikan antara usia dengan kadar gula darah kecuali kadar gula darah naughter (puasa) pada saat awal terapi (Bulan ke-0). Gula darah sewaktu awal terapi tidak menunjukkan perbedaan dengan nilai $\mathrm{p}$ sebesar $0,289(\mathrm{p}>0,05)$ namun nilai $\mathrm{p}$ gula darah naughter awal terapi sebesar 0,040 ( $\mathrm{p}<0,05)$. Terapi bulan kesatu juga tidak menunjukkan adanya perbedaan signifikan yang ditunjukkan dari nilai p gula darah sewaktu $0,242(\mathrm{p}>0,05)$ dan nilai $\mathrm{p}$ gula darah naughter sebesar 0,150 ( $\mathrm{p}>0,05)$. Terapi bulan kedua menunjukkan tidak ada perbedaan signifikan dengan nilai $\mathrm{p}$ gula darah sewaktu $0,658$ ( $\mathrm{p}>0,05)$, nilai $\mathrm{p}$ gula darah naughter sebesar 0,557 ( $\mathrm{p}>0,05)$, nilai $\mathrm{p}$ HbA1C sebesar 0,711 ( $\mathrm{p}>0,05)$ sehingga dapat diartikan pasien melakukan kontrol gula darah dengan baik sehingga komplikasi penyakit dan usia tidak mempengaruhi gula darah.

\section{Pembahasan}

Penelitian dilakukan di Puskesmas Jetis 1 Bantul pada Desember 2019 - Februari 2020. Data diambil secara retrospektif pada pasien diabetes mellitus tipe 2 yang melakukan kontrol di Puskesmas Jetis 1 Bantul pada periode September 2019 hingga November 2019 melalui data rekam medis pasien sebagai sumber data penelitian.

Sampel yang terekrut berjumlah 46 pasien. Teknik pengambilan sampel yang digunakan adalah purposive sampling karena pengambilan sampel ditentukan berdasarkan kriteria inklusi yang sudah ditentukan peneliti. Penelitian telah diulas dan disetujui oleh Komisi Etik Penelitian (KEP) Universitas Ahmad Dahlan dengan No. 011909098.

\section{Karakterisitik Pasien}

Karakteristik pasien meliputi, jenis kelamin, usia, pendidikan, pernikahan, komplikasi penyakit. Gambaran karakteristik pasien dapat dilihat pada tabel 1.

Penderita diabetes mellitus berusia 35 - 64 Tahun sebanyak 30 pasien $(65,2 \%)$ dan 65 tahun sebanyak 16 orang $(34,8 \%)$. Jumlah pasien berdasarkan usia sebanding lurus dengan Riskesdas 2018 menjelaskan jumlah pasien diabetes mellitus paling banyak berusia 35 - 64 Tahun.

Prevalensi pasien diabetes mellitus tipe 2 berjenis kelamin perempuan jauh lebih banyak yaitu 30 pasien perempuan $(65,2 \%)$ sementara pasien laki-laki berjumlah 16 pasien $(34,8 \%)$. Diabetes mellitus tipe 2 juga menyebabkan terjadinya komplikasi penyakit. Prevalensi pasien diabetes dengan komplikasi penyakit sebanyak 33 pasien $(71,7 \%$ ) sementara pasien tanpa komplikasi penyakit sebanyak 17 pasien (28,3\%). Menurut Luijks et al. (2015), komplikasi penyakit dapat memperburuk kontrol terapi diabetes mellitus jangka panjang sehingga terapinya harus disesuaikan kembali agar mencapai target terapi yaitu berupa terkontrolnya gula darah dan komplikasinya.

Pasien berstatus tidak bekerja sebanyak 28 pasien $(60,9 \%)$ sementara 18 pasien $(39,1 \%)$ berstatus bekerja. Jumlah orang yang tidak bekerja jauh lebih banyak dibanding yang bekerja.

Berdasarkan tabel karakteristik pasien, jumlah orang su- dah menikah sebanyak 46 pasien $(100 \%)$. Menurut penelitian Dellafiore et al. (2018) menyatakan pernikahan memberi dampak terhadap kehidupan baik sebelum atau sesudah didiagnosa diabetes. pernikahan dapat memberi dukungan kepada pasangan dengan cara memberi motivasi agar mengontrol gula darah sehingga dapat menjaga kesehatan.

Taraf pendidikan dapat meningkatkan wawasan, pemahaman, dan kepedulian diri tentang penyakit. Jumlah penderita diabetes mellitus tipe 2 terhadap pendidikan didapatkan 9 pasien tidak sekolah, 21 pasien mendapat pendidikan dasar, 14 pasien mendapat pendidikan menengah dan 2 pasien mendapat pendidikan tinggi. Hasilnya sebanding dengan penelitian Kalkan et al. (2019) yang menyatakan jumlah diabetes mellitus tipe 2 berkurang seiring meningkatnya jenjang pendidikan.

\section{Gambaran Gula Darah}

Pengukuran gula darah umumnya menggunakan alat glukometer beserta stripnya namun juga ada yang menggunakan persentase kadar HbA1C. Hasil pengukuran kadar gula darah menggunakan glukometer lebih cepat dibanding HbA1C. Tingkat keakurasian HbA1C lebih tinggi dibanding glukometer yang akurasi akurasinya sekitar 70\% - 80\% (Kermani et al., 2017). Metode pengukurannya digunakan beberapa metode yaitu Gula Darah Sewaktu (GDS) dengan batasnya $154 \mathrm{mg} / \mathrm{dL}$, Gula Darah Naughter (GDN) atau istilah dari Gula Darah Puasa (GDP) yang digunakan di Puskesmas Jetis 1 Bantul dengan batasnya $152 \mathrm{mg} / \mathrm{dL}$ dan $\mathrm{HbA} 1 \mathrm{C} 7 \%$ (PERKENI, 2019) yang menjadi pengontrolan gula darah.

Gambaran data di tabel 2 merupakan gambaran gula darah di Puskesmas Jetis 1 Bantul. Pengukuran gula darah yang digunakan adalah kadar gula darah sewaktu pada awal terapi (bulan ke-0), bulan kesatu dan kedua, kadar gula darah naughter pada awal terapi, bulan kesatu dan kedua, dan HbA1C pada bulan kedua. Kadar gula darah sewaktu secara berurutan sebesar $137,86 \mathrm{mg} / \mathrm{dL} \pm 53,08 \mathrm{mg} / \mathrm{dL}, 142,78$ $\mathrm{mg} / \mathrm{dL} \pm 39,80 \mathrm{mg} / \mathrm{dL}, 112,67 \mathrm{mg} / \mathrm{dL} \pm 18,01 \mathrm{mg} / \mathrm{dL}$. Hasil rata-rata pengukuran gula darah sewaktu mengalami kenaikan pada saat awal terapi ke bulan kesatu dan penurunan di bulan kedua. Hasil rata-rata pengukuran kadar gula darah naughter secara berurutan sebesar $157,15 \mathrm{mg} / \mathrm{dL} \pm 52,18$ $\mathrm{mg} / \mathrm{dL}, 133,32 \mathrm{mg} / \mathrm{dL} \pm 28,97 \mathrm{mg} / \mathrm{dL}, 134,48 \mathrm{mg} / \mathrm{dL} \pm 31,70$ $\mathrm{mg} / \mathrm{dL}$. Hasil rata-rata pengukuran kadar gula darah naughter menunjukkan adanya sedikit fluktuasi pada pengukuran gula darah bulan kesatu ke bulan kedua. Fluktuasi gula darah dapat dianggap normal selama di bawah batas. Beberapa alasan gula darah ada di atas batas normal ialah karena masyarakat merasa sehat, lupa, meminum obat tradisional dan juga tidak tahan terhadap efek samping (Riskesdas, 2018). Hasil ratarata pengukuran $\mathrm{HbA} 1 \mathrm{C}$ pada bulan kedua sebesar $6,87 \% \pm$ $0,52 \%$. Pengukuran menggunakan $\mathrm{HbA} 1 \mathrm{C}$ ini hanya dilakukan oleh beberapa pasien di satu desa saja. Berdasarkan hasil didapatkan terapi yang dilakukan oleh pasien membuat pasien dapat mengontrol gula darah yang merupakan target gula darah sesuai dengan PERKENI 2019 meskipun saat pengukuran gula darah naughter awal terapi melebihi batas namun dapat kembali dikontrol.

Pentingnya melakukan kontrol akan diabetes adalah mencegah terjadinya gula darah di bawah standar karena dapat menyebabkan hipoglikemia sementara ketika gula darah berlebih menjadi hiperglikemia. Dampak buruk apabila gula darah tidak dikontrol adalah timbulnya komplikasi diabe- 
TABel 2: GaMbaran Gula DaraH

\begin{tabular}{llllll}
\hline Waktu Pengukuran & Jenis Pengukuran Gula Darah & $\mathrm{n}$ & $\%$ & Rata-rata $\pm \mathrm{SD}$ & minimum-maksimum \\
\hline \multirow{2}{*}{ Bulan Ke-0 } & Gula Darah Sewaktu & 7 & 15,2 & $137,86 \pm 53,08 \mathrm{mg} / \mathrm{dL}$ & $73-234 \mathrm{mg} / \mathrm{dL}$ \\
& Gula Darah Naughter & 39 & 84,8 & $157,15 \pm 52,18 \mathrm{mg} / \mathrm{dL}$ & $98-296 \mathrm{mg} / \mathrm{dL}$ \\
Bulan Ke-1 & Gula Darah Sewaktu & 9 & 19,6 & $142,78 \pm 39,80 \mathrm{mg} / \mathrm{dL}$ & $88-228 \mathrm{mg} / \mathrm{dL}$ \\
& Gula Darah Naughter & 37 & 80,4 & $133,32 \pm 28,97 \mathrm{mg} / \mathrm{dL}$ & $84-201 \mathrm{mg} / \mathrm{dL}$ \\
Bulan Ke-2 & Gula Darah Sewaktu & 6 & 13,0 & $112,67 \pm 18,01 \mathrm{mg} / \mathrm{dL}$ & $77-128 \mathrm{mg} / \mathrm{dL}$ \\
& Gula Darah Naughter & 31 & 67,4 & $134,48 \pm 31,70 \mathrm{mg} / \mathrm{dL}$ & $88-249 \mathrm{mg} / \mathrm{dL}$ \\
& HbA1C & 9 & 19,6 & $6,87 \pm 0,52 \%$ & $6,2-8,1 \%$ \\
\hline
\end{tabular}

TABEl 3: PenggunaAn obat antidiabetes berdas ARKAN JENIS OBAT

\begin{tabular}{lllllll}
\hline \multirow{2}{*}{ Obat Antidiabetes yang digunakan } & \multicolumn{2}{c}{ Bulan Ke-0 } & \multicolumn{2}{c}{ Bulan Ke-1 } & \multicolumn{2}{c}{ Bulan Ke-2 } \\
\cline { 2 - 7 } & $\mathrm{n}$ & $\%$ & $\mathrm{n}$ & $\%$ & $\mathrm{n}$ & $\%$ \\
\hline Metformin 1 x 1 500 mg & 8 & 17,4 & 9 & 19,6 & 8 & 17,4 \\
Metformin 2 x 1 500 mg & 23 & 50,0 & 22 & 47,8 & 23 & 50,0 \\
Metformin 2 x 1 500 mg + Glimepirid 1 x 1 1 mg & 10 & 21,7 & 9 & 19,6 & 8 & 17,4 \\
Metformin 2 x 1 500 mg + Glimepirid 1 x 1 2 mg & 2 & 4,3 & 1 & 2,2 & 1 & 2,2 \\
Metformin 2 x 1 500 mg + Glimepirid 2 x 1 1 mg & 3 & 6,5 & 5 & 10,9 & 6 & 13,0 \\
Total & 46 & 100 & 46 & 100 & 46 & 100 \\
\hline
\end{tabular}

TABel 4: PenggunaAn obat antidiabetes berdasarkan JENIS TERAPI

\begin{tabular}{lllllll}
\hline \multirow{2}{*}{ Jenis Terapi } & \multicolumn{2}{c}{ Bulan Ke-0 } & \multicolumn{2}{c}{ Bulan Ke-1 } & \multicolumn{2}{c}{ Bulan Ke-2 } \\
\cline { 2 - 7 } & $\mathrm{n}$ & $\%$ & $\mathrm{n}$ & $\%$ & $\mathrm{n}$ & $\%$ \\
\hline Tunggal & 31 & 67,4 & 31 & 67,4 & 31 & 67,4 \\
Kombinasi & 15 & 32,6 & 15 & 32,6 & 15 & 32,6 \\
Total & 46 & 100 & 46 & 100 & 46 & 100 \\
\hline
\end{tabular}

tes mellitus seperti gangguan saraf, gangguan penglihatan, diabetes ketoasidosis, ulkus diabetes, jantung dan komplikasi lain. HbA1C merupakan standar untuk kontrol glikemik sebagai cerminan dari akumulasi glukosa dalam darah sementara pengawasan gula darah secara mandiri merupakan landasan perawatan untuk mendapatkan informasi setiap hari. Keuntungan pengukuran $\mathrm{HbA1C}$ adalah hasil yang diberikan lebih stabil dibanding gula darah puasa, dalam pengukurannya tidak diperlukan pasien dalam keadaan berpuasa atau tidak, dan informasi hasil pengukuran $\mathrm{HbA1C}$ direkomendasikan lebih kuat. Kelemahan HbA1C adalah adanya probabilitas terpengaruh oleh kondisi klinis tertentu seperti merokok, hamil, anemia dan lain-lain.

Peninjauan kembali terapi farmakologi yang dilakukan oleh praktisi saat pasien telah melakukan terapi selama 2-3 bulan. Pemberian jangka waktu selama 2-3 bulan dilakukan karena eritrosit akan bertahan dalam darah selama kurang lebih 120 hari. Eritrosit akan terus diglikasi begitu juga dengan HbA1C yang akan merefleksikan paparan kadar glukosa darah rata-rata yang sudah terintegrasi (Kuenen, 2013).

\section{Gambaran Penggunaan Obat Antidiabetes}

PERKENI (2019) menjelaskan untuk algoritma dalam penggunaan obat antidiabetes, pasien baru menggunakan terapi tunggal terlebih dahulu. Pasien dengan pengecekan rutin dapat diulas kembali terapinya berhasil atau tidak dari kadar gula darah yang diukur. Jika terapi yang dilakukan berhasil, maka terapi yang diberikan selanjutnya akan tetap sama. Jika terapi yang dilakukan gagal atau kadar gula darah di atas normal dan tidak terkendali, maka obat yang digunakan akan ditingkatkan menjadi terapi kombinasi dua obat. Jika target terapi masih belum tercapai, maka ditingkatkan jadi terapi kombinasi tiga obat.

Berdasakan tabel 3, sebanyak 31 pasien $(67,4 \%)$ diberi terapi tunggal dengan menggunakan 1 jenis obat saat awal terapi hingga bulan kedua berturut-turut yaitu metformin $500 \mathrm{mg}$ satu kali sehari dikonsumsi oleh 8 pasien $(17,4 \%), 9$ pasien $(19,6 \%), 8$ pasien $(17,4 \%)$. metformin $500 \mathrm{mg}$ dua kali sehari dikonsumsi oleh 23 pasien $(50,0 \%), 22$ pasien $(47,8 \%), 23$ pasien $(50,0 \%)$. Lima belas pasien $(32,6 \%)$ diberikan obat diabetes kombinasi metformin dan glimepiride. Kombinasi metformin $500 \mathrm{mg}$ dua kali sehari dan glimepiride $1 \mathrm{mg}$ satu kali sehari dikonsumsi 10 pasien (21,7\%), 9 pasien (19,6\%), 8 pasien $(17,4 \%)$. Kombinasi metformin $500 \mathrm{mg}$ dua kali sehari dan glimepiride $2 \mathrm{mg}$ satu kali sehari dikonsumsi oleh 2 pasien $(4,3 \%), 1$ pasien $(2,2 \%), 1$ pasien $(2,2 \%)$. Kombinasi metformin $500 \mathrm{mg}$ dua kali sehari dan glimepiride $1 \mathrm{mg}$ dua kali sehari 3 pasien (6,5\%), 5 pasien (10,9\%), 6 pasien $(13,0 \%)$.

Berdasarkan jenis terapi dan jenis obat, obat antidiabetes yang digunakan pada terapi tunggal adalah metformin dengan aturan penggunaan pada tabel. Metformin digunakan sebagai obat pilihan terapi tunggal dibanding glimepiride karena metformin mampu mengontrol indeks massa tubuh dan indeks metabolisme lemak (Zhu et al., 2013). Metformin juga lebih aman dibandingkan glimepiride sebagai obat pilihan terapi tunggal karena tidak memberikan efek hipoglikemia. Pemberian kombinasi obat antidiabetes kombinasi diberikan karena pemberian efikasi terapi tunggal tidak sebaik dengan terapi kombinasi serta tidak tercapainya target terapi tunggal untuk mencapai kadar gula darah yang diharapkan pada pasien tertentu sehingga diberikan terapi kombinasi dua obat. Pasien dengan terapi kombinasi dua obat semula diberi dosis dan frekuensi metformin $500 \mathrm{mg}$ dua kali sehari dan glimepiride satu kali sehari. Jika dosis tersebut tidak berpengaruh dengan kadar gula darah, maka frekuensi glimepiride dinaikkan menjadi dua kali sehari $1 \mathrm{mg}$.

Perubahan dosis dan frekuensi juga terjadi saat terapi ditunjukkan pada terapi tunggal pada periode bulan ke-0 dan 
TABEL 5: PERBEDAAN KADAR GULA DARAH BERDASARKAN USIA

\begin{tabular}{llccccc}
\hline \multirow{2}{*}{ Waktu } & \multirow{3}{*}{ Kadar Gula Darah } & \multicolumn{4}{c}{ Usia (Tahun) } & \multirow{2}{*}{ p - value } \\
\cline { 3 - 5 } & & $\mathrm{N}$ & $\% 5-64$ & $\mathrm{~N}$ & $\%$ & \\
\hline \multirow{2}{*}{ Bulan ke-0 (awal terapi) } & Gula Darah Sewaktu & 4 & 8,70 & 3 & 6,50 & 0,289 \\
& Gula Darah Naughter & 26 & 56,50 & 13 & 28,30 & $0,040 *$ \\
Bulan Ke-1 & Gula Darah Sewaktu & 7 & 15,20 & 2 & 4,30 & 0,242 \\
& Gula Darah Naughter & 23 & 50,00 & 14 & 40,50 & 0,150 \\
Bulan Ke-2 & Gula Darah Sewaktu & 3 & 6,50 & 3 & 6,50 & 0,658 \\
& Gula Darah Naughter & 23 & 50,00 & 8 & 17,40 & 0,557 \\
& HbA1C & 4 & 8,70 & 5 & 10,90 & 0,711 \\
\hline
\end{tabular}

Uji yang digunakan adalah uji Kruskal Wallis dengan tingkat kepercayaan 95\%. *memiliki perbedaan signifikan $(\mathrm{p}<0,05)$.

TABEL 6: PERBEDAAN KADAR GULA DARAH BERDASARKAN KOMPLIKASI PENYAKIT

\begin{tabular}{lllllll}
\hline \multirow{3}{*}{ Waktu } & & \multicolumn{3}{c}{ Komplikasi Penyakit } & \\
\cline { 3 - 6 } & Kadar Gula Darah & \multicolumn{3}{c}{ Ada } & \multicolumn{3}{c}{ Tidak Ada } & p - value \\
\cline { 3 - 5 } & & $\mathrm{N}$ & $\%$ & $\mathrm{~N}$ & $\%$ & \\
\hline \multirow{2}{*}{ Bulan ke-0 (awal terapi) } & Gula Darah Sewaktu & 6 & 13,00 & 1 & 2,20 & 0,317 \\
& Gula Darah Naughter & 27 & 58,70 & 12 & 26,10 & 0,626 \\
Bulan Ke-1 & Gula Darah Sewaktu & 6 & 13,00 & 3 & 6,50 & 0,121 \\
& Gula Darah Naughter & 27 & 58,70 & 10 & 21,80 & 0,932 \\
Bulan Ke-2 & Gula Darah Sewaktu & 3 & 6,50 & 3 & 6,50 & 0,658 \\
& Gula Darah Naughter & 23 & 50,00 & 8 & 17,40 & 0,214 \\
& HbA1C & 7 & 15,20 & 2 & 4,30 & 0,104 \\
\hline
\end{tabular}

Uji yang digunakan adalah uji Kruskal Wallis dengan tingkat kepercayaan 95

bulan ke-1 terjadi karena target pengontrolan gula darah belum tercapai/kurang efektif. Perubahan pada terapi tunggal pada periode bulan ke-2 juga kembali ke awal (bulan ke-0). Terapi kombinasi juga mengalami frekuensi serta kenaikan dosis dari metformin $500 \mathrm{mg}$ dua kali sehari kombinasi dengan glimepiride $1 \mathrm{mg}$ satu kali sehari menjadi metformin 500 mg dua kali sehari kombinasi dengan glimepiride $1 \mathrm{mg}$ dua kali sehari. Perubahan terapi kombinasi metformin $500 \mathrm{mg}$ dua kali sehari dengan glimepiride $2 \mathrm{mg}$ satu kali sehari juga menurun dari 2 pasien di bulan ke- 0 menjadi 1 pasien di bulan ke-1 dan bulan ke-2. Perubahan dosis serta frekuensi ini bertujuan menekan kadar gula darah dan juga memudahkan pasien mengingat waktu konsumsi obat sehingga pasien mendapatkan pencapaiannya berupa terkontrolnya kadar gula darah.

\section{Evaluasi Kadar Gula Darah Berdasarkan Usia dan Komplikasi Penyakit}

Berdasarkan penelitian Shou et al. (2020), dijelaskan penuaan menjadi pengaruh terjadi diabetes mellitus dan komplikasi. Bertambahnya usia dapat meningkatkan penuaan otot kerangka (skeletal muscle). Penuaan otot kerangka meningkatan resiko terjadinya resistensi insulin pada otot kerangka yang mempengaruhi sensitivitas insulin. Risiko terjadinya diabetes mellitus tipe 2 dapat meningkat melalui jalur resistensi insulin dan jalur disfungsu sel pankreas. Jalur resistensi insulin diakibatkan oleh disfungsi mitokondria, stres retikulum endoplasma, meningkatnya produksi reactive oxygen species (ROS), meningkatkan akumulasi lipid mioseluler, meningkatnya stres oksidatif, meningkatnya risiko sarkopenia, aktivasi sistem renin-angiotensin, dan menurunnya autofagi (Shou et al., 2020). Jalur disfungsi sel pankreas juga mengakibatkan terjadinya diabetes mellitus dengan cara disfungsi mitokondria, berkurangnya jumlah GLUT2, berkurangnya respon terhadap GLP-1 dan terganggunya penanganan Ca2+ (De Tata, 2014). Penelitian Rahayu et al. (2020), menunjukkan adanya hubungan usia dengan kadar gula darah. Penelitian Wardani et al. (2014), menunjukkan adanya pasien diabetes yang mengalami komplikasi penyakit.

Berdasarkan hadirnya komplikasi penyakit, tujuh pasien melakukan pengukuran gula darah sewaktu terdiri atas 6 pasien (13\%) dengan usia 35-64 tahun dan 1 pasien $(2,2 \%)$ dengan usia 65 tahun. Tiga puluh sembilan pasien melakukan pengukuran gula darah naughter atau gula darah puasa terdiri atas 27 pasien $(58,7 \%)$ dengan usia 35-64 tahun dan 12 pasien $(26,1 \%)$ dengan usia 65 tahun. Sembilan pasien melakukan pengecekan gula darah sewaktu terdiri atas 6 pasien $(13 \%)$ dengan usia 35-64 tahun dan 3 pasien $(6,5 \%)$ dengan usia 65 tahun. Tiga puluh tujuh pasien melakukan pengukuran gula darah naughter terdiri atas 27 pasien $(58,7 \%)$ dengan usia 35-64 tahun dan 10 pasien $(21,8 \%)$ dengan usia 65 tahun pada bulan kesatu. Enam pasien melakukan pengukuran gula darah sewaktu terdiri atas 3 pasien $(6,5 \%)$ dengan usia 35-64 tahun dan 3 pasien $(6,5 \%)$ dengan usia 65 tahun. Tiga puluh tujuh pasien melakukan pengukuran gula darah naughter terdiri atas 23 pasien (50\%) dengan usia 35-64 tahun dan 8 pasien $(17, \%)$ dengan usia 65 tahun. Sembilan pasien melakukan pengukuran $\mathrm{HbA} 1 \mathrm{C}$ terdiri atas 7 pasien $(15,2 \%)$ dengan usia 35-64 tahun dan 2 pasien $(4,3 \%)$ dengan usia 65 tahun pada bulan kedua.

Evaluasi kadar gula darah pasien dapat diketahui berdasarkan usia dan komplikasi penyakit dengan cara mengetahui perbedaan berdasarkan usia dan komplikasi penyakit. Besar perbedaan dapat diketahui melalui uji Kruskal Wallis. Uji Kruskal Wallis ini dilakukan dengan perangkat lunak SPSS Versi 26. Uji Kruskal Wallis dipilih karena distribusi data ti- 


\section{dak normal.}

Penentuan suatu penyakit dikategorikan sebagai komplikasi atau bukan dilakukan dengan cara menentukan penyakit lain hadir saat pasien setelah didiagnosa diabetes mellitus atau selama masa rawat jalan pasien diabetes mellitus. Pasien yang mengalami komplikasi penyakit berjumlah 33 pasien sementara 13 pasien lainnya tidak mengalami komplikasi penyakit. Uji Kruskal Wallis menunjukkan tidak adanya perbedaan signifikan komplikasi penyakit dengan gula darah. nilai $\mathrm{p}$ menunjukkan dengan nilai $\mathrm{p}$ kadar gula darah sewaktu 0,317 ( $\mathrm{p}>0,05)$, nilai $\mathrm{p}$ kadar gula darah naughter sebesar $0,626$ ( $p>0,05)$ pada bulan awal terapi. Terapi bulan kesatu menunjukkan tidak ada perbedaan signifikan dengan nilai p kadar gula darah sewaktu 0,121 ( $\mathrm{p}>0,05)$, nilai $\mathrm{p}$ kadar gula darah naughter sebesar 0,932 ( $\mathrm{p}>0,05)$. Terapi bulan ketiga juga menunjukkan tidak terdapat perbedaan signifikan ditunjukkan dengan nilai $\mathrm{p}$ kadar gula darah sewaktu sebesar $0,658$ ( $\mathrm{p}>0,05)$, nilai $\mathrm{p}$ kadar gula darah naughter sebesar $0,214$ ( $\mathrm{p}>0,05)$ dan nilai $\mathrm{p} \mathrm{HbA1C}$ sebesar 0,104 ( $\mathrm{p}>0,05)$.

Hasil uji perbedaan baik pada usia maupun komplikasi penyakit tidak menunjukkan adanya perbedaan signifikan terhadap gula darah dapat diartikan bahwa tidak ada pengaruh terhadap kadar gula darah berdasarkan usia dan komplikasi penyakit. Gula darah bisa dipengaruhi oleh aktivitas fisik, diet, stres dan lain-lain. Aktivitas fisik mempengaruhi kadar gula darah. Semakin tinggi tingkat aktivitas fisik, maka semakin terkontrol kadar gula darah (Putri et al., 2019). Diet juga mempengaruhi kadar gula darah. Melakukan intermittent fasting, diet, defisit kalori dapat menurunkan kadar gula darah puasa dan kadar gula darah post prandial (Arnason et al., 2017). Tekanan juga berpengaruh terhadap kontrol gula darah. Semakin besar tekanan secara psikis semakin buruk kepatuhan dalam mengonsumsi obat. Semakin buruk kepatuhan, semakin buruk kontrol gula darahnya (Vasanth et al., 2019). Berdasarkan Riskesdas (2018), buruknya kontrol dipengaruhi oleh pasien juga. Hal ini dikarenakan adanya pasien yang merasa sudah sehat, tidak rutin atau malas ke puskesmas, lupa mengonsumsi obat, harga obat yang harus dibeli tidak terjangkau. Penegakkan dalam rutinnya mengonsumsi obat dan rutin kontrol ke fasilitas pelayanan kesehatan dapat meningkatkan kontrol gula darah. Penelitian hanya menggunakan data rekam medis pasien diabetes mellitus tipe 2 di Puskesmas Jetis 1 Bantul. Kuesioner seperti gaya hidup, aktivitas fisik, dan lain-lain dapat dilengkapi untuk memperkuat penelitian dan menghindari bias.

\section{KESIMPULAN}

Berdasarkan analisis penelitian dengan menggunakan data rekam medis pasien rawat jalan diabetes mellitus tipe 2 pada periode September 2019 sampai November 2019, didapatkan kesimpulan yaitu hasil uji Kruskal Wallis didapatkan nilai $p$ 0,$289 ; 0,242 ; 0,150 ; 0,658 ; 0,557 ; 0,711(p>0,05) ; 0,040$ $(p<0,05)$ yang menjelaskan tidak adanya perbedaan signifikan pada gula darah berdasarkan usia. Nilai $p 0,317 ; 0,626$; 0,$121 ; 0,932 ; 0,658 ; 0,214 ; 0,104(p>0,05)$ menunjukkan tidak adanya perbedaan signifikan pada gula darah berdasarkan komplikasi penyakit.

\section{UCAPAN TERIMA KASIH}

Peneliti berterimakasih kepada Allah SWT, dosen pembimbing, staf Puskesmas Jetis 1 Bantul, dan rekan-rekan yang terlibat dalam penyelesaian penelitian.

\section{Daftar Pustaka}

American Diabetes Association, 2018, Standards of medical care in diabetes-2018, The Journal of Clinical and Applied Research and Education, 41(1), S13.

Anonim, 2017, Profil Puskesmas Jetis 1 tahun 2017, Puskesmas Jetis 1 Bantul, Yogyakarta. Arnason, T. G., Bowen, M. W., Mansell, K. D., 2017, Effects of intermittent fasting on health markers in those with type 2 diabetes: A pilot study, World J Diabetes 2017 ; 8(4): 154-164.

De Tata, Vincenzo, 2014, Age-related impairment of pancreatic beta-cell function: pathophysiological and cellular mechanisms, Endocrinology of Aging, 5(138). Dellafiore, F., Rosa, D., Caruso, MP., Allemano, M., Caruso, R., 2018, The impact of type 2 diabetes diagnosis on married couples, Journal of Diabetes Nursing, 22: JDN12.

International Diabetes Federation, 2015, IDF Diabetes Atlas Seventh Edition, Inggris. Kalkan, I., Kiliçarslan, M., 2019, Type 2 Diabetes Mellitus (Type 2 DM) incidence and associated factors: a cross sectional study in Istanbul, Turkey, Progress in Nutrition 2019, 21(4): 917-921.

Kuenen, Judith C., 2013, Measures of glycemic control: do we need more than HbA1c, Vrije Universiteit, Netherlands.

Luijks, H., Biermans, M., Bor, H., van Weel, C., LagroJanssen, T., de Grauw, W. 2015. The Effect of Comorbidity on Glycemic Control and Systolic Blood Pressure in Type 2 Diabetes: A Cohort Study with 5 Year FollowUp in Primary Care. PLoS ONE, 10(10).

PERKENI, 2015, Pengelolaan dan Pencegahan Diabetes Melitus Tipe 2 di Indonesia, PERKENI, Jakarta.

PERKENI, 2019, Pengelolaan dan Pencegahan Dibetes Mellitus Tipe 2 Dewasa di Indonesia, PERKENI, Jakarta

Putri, M., Persariningrat, Rd. T. I., Surialaga, S., Syamsunamo, M. R. A. A., 2019, Physical Activities Decrease Fasting Blood Glucose Level in Diabetes Mellitus Type 2 Patients: Use of International Physical Activity Questionnaire (IPAQ) in Rural Area, MKB, 51(4): 201-5.

Rahayu, S., Komariah., 2020, Hubungan usia, jenis kelamin dan indeks massa tubuh dengan kadar gula darah puasa pada pasien diabetes mellitus tipe 2 di Klinik Pratama Rawat Jalan Proklamasi, Depok, Jawa Barat. Jurnal Kesehatan Kusuma Husada.

Riset Kesehatan Dasar (Riskesdas), 2018, Hasil Utama Riskesdas 2018, Badan Penelitian dan Pengembangan Kesehatan Kementerian RI, Diakses tanggal 21 Agustus 2019.

Selvin, E., Parrinello, C. M., 2013, Age-related differences in glycaemic control in diabetes, Diabetologia 2013, $56(12)$.

Shou, J., Chen, P. J., Xiao, W. H., 2020, Mechanism of increased risk of insulin resistance in aging skeletal muscle. Diabetol Metab Syndr, 12(14).

Vasanth, R., Ganesh, Aparna., Shanker, R., 2017, Impact of Stress on Type 2 Diabetes Mellitus Management, Psychiatria Danubina, 29(3): 416-421.

Wardani, A. K., Isfandiari, M. A., 2014, Hubungan dukungan keluarga dan pengendalian kadar gula darah dengan gejala komplikasi mikrovaskuler, Jurnal Berkala Epidemiologi, 2(1): 1-12. WHO, 2016, Global Report On Diabetes, Perancis. WHO, 2016, 
World Health Organization - Diabetes Country Profiles, diunduh dari https://www.who.int/diabetes/countryprofiles/idn ${ }_{e} n . p d f$.

Zhu, H., Zhu, S., Zhang, X., Guo, Y., Shi, Y., Chen, Z., Leung, S. W., 2013, Comparative efficacy of glimepiride and metformin in monotherapy of type 2 diabetes mellitus: meta-analysis of randomized controlled trials, Diabetology metabolic syndrome, 5(1): 70. 